\title{
The Determinants of Financial Participation Impact on Firm Performance: A Meta-Regression Approach
}

\author{
Olfa Aissa $^{1}$ \\ ${ }^{1}$ Higher Institute of Management of Tunis, Department of Finance, DEFI Research Unit, Tunisia \\ Correspondence: Olfa Aissa, Higher Institute of Management of Tunis, Department of Finance, 41, Rue de la \\ Liberté, Cité Bouchoucha 2000 Le Bardo, Tunis, Tunisia. E-mail: olfa.aissa@isg.rnu.tn
}

Received: March 15, 2016

Accepted: April 15, 2016

Online Published: April 25, 2016

doi:10.5539/ijef.v8n6p151

URL: http://dx.doi.org/10.5539/ijef.v8n6p151

\begin{abstract}
Financial participation has emerged as a convenient way to converge employees' interest with that's of shareholders; it is then presumed to contribute to firm performance. To investigate the determinants of this incentive pay, a meta-regression analysis was conducted. Findings suggest that the relationship between employees' financial participation and firm performance is influenced by three types of moderating factors related to structural, managerial and organizational characteristics.
\end{abstract}

Keywords: employees' financial participation, firm performance, meta-regression analysis

\section{Introduction}

The contractual approach endeavors to bring efficient answers to the problems raised by the divergences of interests of the partners in the firm (Berle \& Means, 1932; Coase, 1937; Alchian \& Demsetz, 1972, 1973; Jensen \& Meckling, 1976; Williamson, 1981). Many research tried to bring answers to the key question of the effectiveness of the various modes of resolution of the conflicts between the economic agents evolving in the same firm, as well as lighting on the propensity of these mechanisms to influence the final performance. The financial participation constitutes is one of these mechanisms of incentive and control of firm employees and harmonization of their interests with those of the owners.

The development of employees' financial participation rests on the agency theory which provides a strong theoretical basis for the use of this form of incentive compensation systems by a firm, in order to deal with the problem of conflict of interests between the employees and the shareholders (Jensen \& Meckling, 1976). This conflict of interests leads the leader to control the employees in order to make sure that they behave in the interest of the shareholders thus involving costs called "agency costs". In order to reduce them, the leader has two alternatives.

The first one is to control the employees directly in order to prevent their deviating behaviors. However, the asymmetry of information and the indivisibility of the tasks make difficult this direct supervision, beyond its high cost for the firm (Alchian \& Demsetz, 1972).

The second alternative is to develop interests' aligners like forms of control instead of a direct supervision, namely the financial participation. The presence of a form of incentive compensation, based on the result of the group, encourages mutual control by the members of the same work group, thus to replacing the hierarchical monitoring system by a collective mutual monitoring system. Mirlees (1976) and Holmström (1979) were among the first to show the relevance of the compensation systems related to the firm performance, when the efforts of the employees are imperfectly controlled and when their interests are opposed to those of the firm which employs them.

Overwhelming evidence shows a positive relationship between financial participation and firm performance (see annex), although a few studies report a negative or non-significant relationship (particularly because of the "free-riding" problem evoked by Jensen and Meckling (1979) and Williamson (1980)).

Financial participation is a mechanism that "gives employees a residual claim over part of the firm's surplus, in the form of profit- and gain-sharing or dividends on employee-owned shares and variation in share value" (Poutsma, 2001): 
- Employee share ownership: A firm may offer free or discounted shares to its employees. This scheme is an indirect participation in the firm results either by receiving dividends or by the appreciation of employee-owned capital, or a combination of both.

- Profit-sharing and gain-sharing: it's a form of sharing of profits between firm shareholders and employees. These last are giving, in addition to a fixed wage, a variable compensation directly linked to profits or some other measure of firm results.

The term profit-sharing is used for schemes that are strictly based on profit. Gain-sharing is usually considered as a productivity-improving or cost-reducing activity, not directly related to company profit levels. Essentially, what differentiates profit-sharing from gain-sharing is employee influence degree on firm performance. In the first case, the schemes do not give employees any role in getting the aim; they see badly how they can influence the firm performance. In the second case, employees have a relative influence in reaching the objective; they realize the importance of the influence they have on its realization.

Within the framework of this research, we focus only on profit-sharing and gain-sharing, designed by employees' financial participation.

This study seeks to investigate this important research question: What are the determinants of the relationship between employees' financial participation and firm performance? For this purpose, a meta-regression was conducted allowing the identification of successful condition of the impact of financial participation on firm performance.

The paper is organized as follows. Section 2 reviews the theory behind the relation between employees' financial participation and firm performance. Section 3 describes the meta-regression methodology and the data used. Section 4 presents and discusses the results. Section 5 concludes the paper.

\section{Literature Review}

According to Saint-Onge (1994), rather than asking whether financial profit-sharing plans are effective, one should try to identify the factors influencing its long-term success, factors which can lead, reduce or even reverse such an impact (During et al., 2006).

According to Bullock and Lawler (1984), the success of such incentive compensation depends on factors which are related to the scheme itself (structural characteristics and management characteristics) and with the firm in which it is introduced (organizational characteristics). In this section, we examine the whole literature in order to formulate the research hypotheses.

\subsection{The Structural Characteristics}

\subsubsection{Criteria of the Bonus}

The criteria which are retained in the formula of computation of the bonus must be quantitative, i.e. objective, simple and clear in order to facilitate the comprehension of employees (Kelly \& Hounsell, 2007).

Hypothesis 1: The absence of quantitative criteria of the bonus influences negatively the impact of the employees' financial participation on the firm performance.

\subsubsection{The Value of the Bonus}

Piekkola (2005), studying the impact of different financial participation schemes on the productivity and the profits, confirms that they have a significant influence only if the value is sufficiently raised, that is to say about $3,6 \%$ of the total wage.

Hypothesis 2: The value of the bonus influences positively the impact of the employees' financial participation on the firm performance.

\subsubsection{The Availability of the Bonus}

The immediate provision of the versed sums is more incentive than those which are deferred (i.e. versed on equity fund managed for the employees benefit).

Hypothesis 3: The deferred payment of the bonus influences negatively the impact of the employees' financial participation on the firm performance.

\subsubsection{The Frequency of the Bonus Payments}

According to Coyle-Shapiro et al. (2002), the employees' attitude with respect to the scheme is not favorable if the bonus is not frequently distributed. 
Hypothesis 4: The unicity of the bonus payments influences negatively the impact of the employees' financial participation on the firm performance.

\subsection{The Management Characteristics}

\subsubsection{Multiplicity of the Financial Participation Schemes}

Results of Kato and Morishima (2003) study show that to adopt several schemes at the same time within the firm cause a drop in the productivity.

Hypothesis 5: The multiplicity of the schemes influences negatively the impact of the employees' financial participation on the firm performance.

\subsubsection{The Size of the Group Covered by the Scheme}

In a great work group, the relations become more impersonal leading to a difficulty to control the other team members (Freeman et al., 2010a).

Hypothesis 6: The size of the group covered by the scheme influences negatively the impact of the employees' financial participation on the firm performance.

\subsection{The Organizational Characteristics}

\subsubsection{The Communication within the Firm}

Pendleton et al. (2003) consider that the financial participation and the communication tend to coexist, because they are two demonstrations conceptually distinct from the same phenomenon that to confer on employees more rights within the firm.

Hypothesis 7: The presence of supports of communication positively influences the impact of the financial profit-sharing of paid on the firm performance.

\subsubsection{The Training within the Firm}

According to Pendleton et al., (2003), the firms which share their profits with their employees adopt on average higher budgets of training in order to reinforce the impact of the incentive compensation on their performance.

Hypothesis 8: The presence of training programs influences positively the impact of the employees' financial participation on the firm performance.

\subsubsection{The Social Participation}

Sesil (2006) shows that only the joint presence of the social participation and the financial participation influences positively and significantly the firm's performance measured by the returns on assets.

Hypothesis 9: The presence of participative devices influences positively the impact of the employees' financial participation on the firm performance.

\section{Methodology and Data}

To test the nine hypotheses, we use meta-analysis. Thus, we follow a well defined process which makes it possible to conduct a quantitative analysis of the literature leading to reliable results on the statistical level and allowing to draw a rigorous and exhaustive synthesis from it (Knell \& Smith, 1979).

Meta-analysis, as a statistical treatment mode, offers a standardized and reproducible methodology (Laroche \& Schmidt, 2004). Its interest, in addition to the work of synthesis, is to increase the precision of the final quantification, its representativeness and its generalization and of raising the doubts in the event of discordances between works previously completed.

The procedure that we followed is that of Hunter et al. (1982) and Stanley and Jarrell (1989):

\subsection{Step 1: Collection, Selection and Coding Studies}

The objective of this stage is to obtain the necessary informations for the constitution of database which will used to validate (or not) the conceptual framework which was defined. Within the framework of meta-analysis, the principle of exhaustiveness confers on this stage a characteristic, that to integrate all the literature carried out on the subject of interest. An exhaustive research implies all work independently of their results (which they are identical or contrary to the awaited results) and of their publication or not in scientific reviews (Hunter \& Schmidt, 2004).

In order to build this corpus, we conduct a meticulous and exhaustive search for all existing work, resorting at the same time to computerized databases (jstor, ebscho, sciencesdirects, ssrn, proquest), to electronic editions of 
specialized reviews in editors' sites (blackwell, econpapers, elsvier, emeraldinsight ideas and spinger) and to search engines (google scholar). We also enriched research by carrying out a manual examination by the quotations and references in the studies and the works which cover our research subject. All the academic publications dealing with the relation between the employees' financial participation and the firm performance, materialized by a statistical measurement were retained, without any limitation of date. We stopped the collection of the studies at the end of April 2013. Overall, we could collect 565 studies.

Within the framework of the selection, it should be noted that one of the advantages of meta-analysis, unlike a singular study, is to obtain an estimate of the effect size starting from a broader and diversified population. To reach such a result, the choice should not be too selective, in order to stick to the principle of exhaustiveness.

The base that we obtained will undergo a whole of restrictions justifying the elimination of some of the collected studies. Figure 1 recalls the process of identification and selection of the studies which led to the constitution of the empirical database. Following the various stages of the selection, we retained 70 empirical studies.

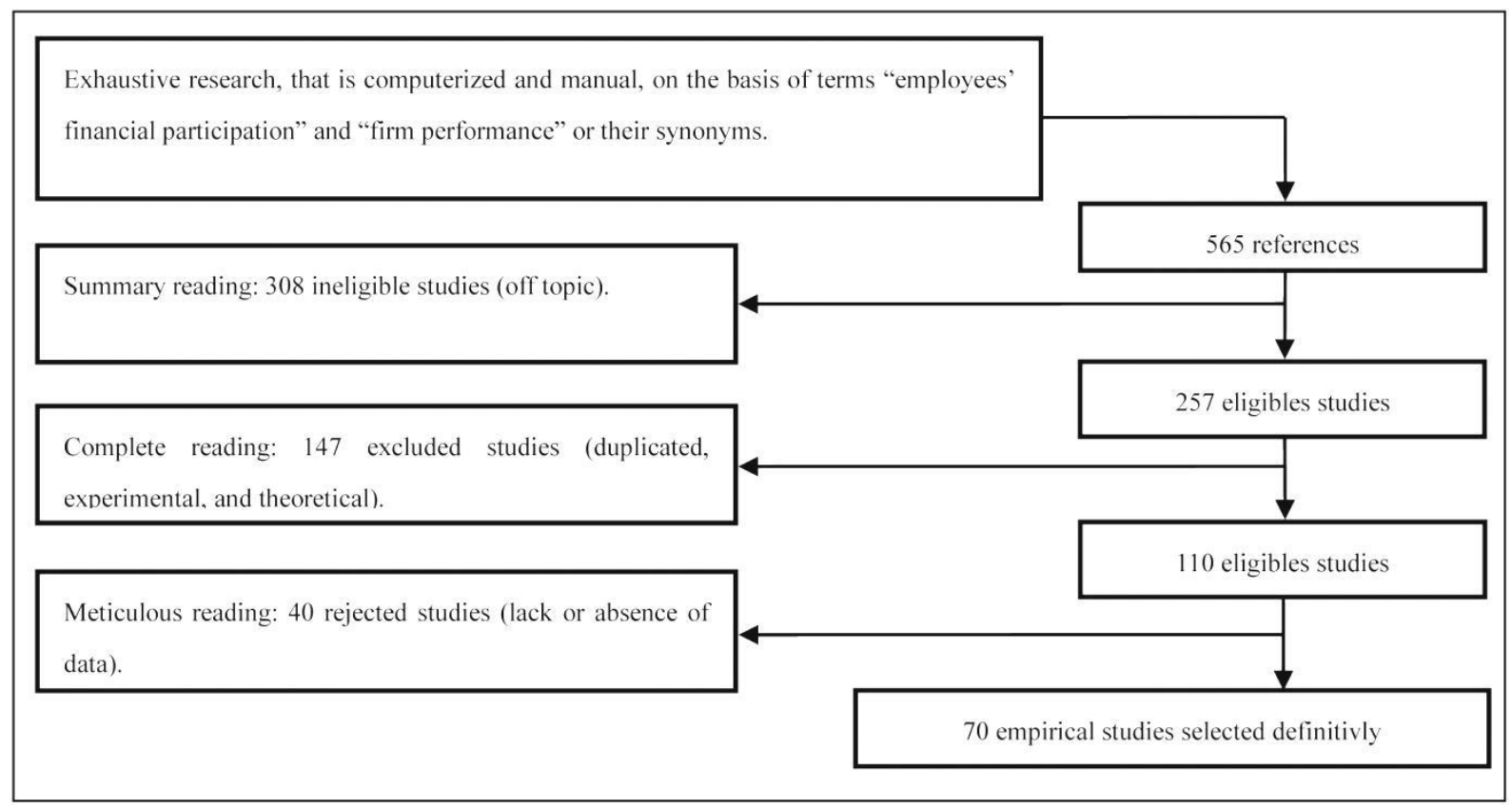

Figure 1. Slection process

The specificity of meta-analysis is to be interested in all the literature. However, and a posteriori, we noted that the database concerns to $92 \%$ firms evolving in developed environments: North America (United States and Canada: 34\%), Western Europe (United Kingdom, France, Germany, etc: 52\%), Far East (Japan, South Korea: $6 \%$ ). The studies which are related to firms in emerging countries (Mexico, Brazil, and China) account for only $6 \%$.

The phase of coding aims to prepare all the observations for the statistical processing (Wilson, 2009). The selected studies are subjected to a process of coding in order to identify the variables which reflect their differences as well as the indicators selected to measure them.

The analysis of the sample of studies allowed to subdivide it in two groups according to whether it is measuring the impact of the financial participation on the accounting performance or on the stock exchange performance.

\subsection{Step 2: The Transformation of the Statistics Available into Same Metric}

At this stage of the analysis, it is question of deciding about the commune metric to retain, called "the effect size", in order to measure the link between the two variables of interest (Glass, 1976, 1977). It is possible to carry out the aggregation of the results only on the condition of retaining the same index and to convert those which are different thanks to the conversion expressions (Borenstein et al., 2009). Two types of indices of effect size are often employed: the standardized difference averages $d$, employed in the framework of the experimental studies and the partial correlation coefficient $r$, used within the framework of the correlation studies. 
All 70 empirical studies made it possible to obtain 226 observations, i.e. partial correlation coefficients (Table 1). The choice of the partial correlation coefficient $r$ as a common indicator was imposed by the number of correlation studies appearing in our sample. Beyond this argument, the choice of the criterion of the partial correlation has a major advantage compared to the calculation of the standardized difference $d$ (Rosenthal \& Dimatteo, 2001): the correlation gives an account of the relation between the level of the financial participation (the independent variable) and the changes anticipated on the level of the performance (the dependant variable). The conversion of $r$ into $d$ would lead to a loss of information on the magnitude of this relation.

Table 1. Distribution of sample studies according to the performance indicator

\begin{tabular}{ccc}
\hline Firm performance indicator & Mesures & Number of partial correlation coefficients \\
\hline Accounting & Productivity & 145 \\
& Sales & 7 \\
& Profits & 15 \\
& ROA & 14 \\
& ROE & 10 \\
ROC & 7 \\
ROI & 5 \\
ROS & 2 \\
\hline Stock market & Tobin's Q & 6 \\
& Stock returns & 5 \\
& Stock value & 4 \\
& Excess value & 2 \\
& Earning per share & 2 \\
& Dividend yield & 1 \\
Total & Exchange rate & 1 \\
\hline
\end{tabular}

Within the framework of our research, the partial correlation coefficient is calculated thanks to the various statistical measurements posted in the selected studies and which formulas are in several works, in particular those of Wolf (1986), Rosenthal (1987) and Hunter and Schmidt (2004).

\subsection{Step 3: The Research of the Moderator Variables}

The aim of this step is to explain the variability of the results between the studies through meta-analysis regression (Stanley \& Jarrell, 1989). It is about a multiple linear regression whose objective is to measure the simultaneous impact of independent variables on the standardized effect size calculated for each study.

The following meta-regression model integrates all of these variables to explain the diverse findings (Stanley \& Jarrell, 1989, p. 165):

$$
b_{j}=\beta+\sum_{k=1}^{K} \alpha_{k} Z_{j k}+e_{j}
$$

Where:

$b_{j}$ Represents the reported estimate of $\beta$ of the $j$ th study in the literature $(j=1,2, \ldots, L)$.

$\beta$ Represents the 'true' value of the parameter of interest.

$Z_{k j}$ Represent the meta-independent variables (moderator variables) $(k=1,2, \ldots, K)$.

$\alpha_{k}$ Represent the meta-regression coefficients.

$e_{j}$ Represents the meta-regression disturbance term.

Within the framework of this research, the objective of meta-regression analysis is to test the impact of independent variables on the relation between the financial participation and firm performance. The regression connects the dependant variable which is the partial correlation coefficient $(r)$ estimated with the level of each study, with these variables.

The analysis of the literature which was carried out within the framework of the second section revealed the 
existence of three types of independent variables which were the subject of the nine hypotheses:

- Those which are relating to the scheme itself.

- Those which are interested in the manner of managing it.

- Those which are specific to the firm where it is introduced.

In addition, the analysis of the various empirical studies revealed other variables which are methodological variables representing specificities of the studies. The integration of these control variables in the model makes it possible to give an account of their potential influence and to measure their real contribution to the differences in the results.

Table 2 synthesizes the totality of the variables, their definition as well as measurements which are allotted to them in the econometric models.

Table 2. Construction of variables

\begin{tabular}{|c|c|c|}
\hline \multicolumn{2}{|r|}{ Variables } & Mesures \\
\hline \multicolumn{3}{|l|}{ Dependent variable } \\
\hline \multicolumn{2}{|c|}{ Partial correlation coefficient within the framework of the linear meta-regression } & $\begin{array}{l}\text { Quantitative variable (the value of the partial } \\
\text { correlation coefficient) }\end{array}$ \\
\hline \multicolumn{2}{|c|}{ Partial correlation coefficient within the framework of the logit meta-regression } & $\begin{array}{l}\text { Binary variable : } 1 \text { if the value is positive and } \\
\text { significant at least with the threshold of } 5 \%, 0 \\
\text { otherwise }\end{array}$ \\
\hline \multicolumn{3}{|l|}{ Independent variables } \\
\hline \multirow[t]{4}{*}{ Structural variables } & Absence of quantitative criteria of the bonus & Binary variables: 1 if yes, 0 otherwise \\
\hline & Value of bonus & Binary variables: 1 if yes, 0 otherwise \\
\hline & Differed payment of bonus & Binary variables: 1 if yes, 0 otherwise \\
\hline & Unicity payment of bonus & Binary variables: 1 if yes, 0 otherwise \\
\hline \multirow[t]{2}{*}{ Management variables } & Multiplicity of schemes & Binary variables: 1 if yes, 0 otherwise \\
\hline & Group size covered by the scheme & Binary variables: 1 if yes, 0 otherwise \\
\hline \multirow[t]{3}{*}{ Organizational variables } & Presence of communication supports & Binary variables: 1 if yes, 0 otherwise \\
\hline & Presence of training programs & Binary variables: 1 if yes, 0 otherwise \\
\hline & Presence of participative devices & Binary variables: 1 if yes, 0 otherwise \\
\hline \multicolumn{3}{|l|}{ Control variables } \\
\hline Performance indicator & Objective & Binary variables: 1 if yes, 0 otherwise \\
\hline Nature of performance indicator & Accounting & Binary variables: 1 if yes, 0 otherwise \\
\hline Financial participation scheme & Profit-sharing & Binary variables: 1 if yes, 0 otherwise \\
\hline Methodological approach & Regression & Binary variables: 1 if yes, 0 otherwise \\
\hline Sector & Industry & Binary variables: 1 if yes, 0 otherwise \\
\hline Study country & United States & Binary variables: 1 if yes, 0 otherwise \\
\hline Study publication & Published & Binary variables: 1 if yes, 0 otherwise \\
\hline Sample size & Sample size & Quantitative variable : Ln (sample size) \\
\hline
\end{tabular}

The analysis of the effect of the explanatory variables on the impact of financial participation is carried out through three models:

- Model (1): we retain the nine independent variables which were the subject of the assumptions of research.

- Model (2): we integrate the control variables.

- Model (3): we use the "backward elimination" procedure.

\section{Meta-Regression Empirical Results: Determinants of Financial Participation Impact on Firm Performance}

The objective of the analysis within the framework of this section is to determine the role of moderating variables on the relation "financial participation - firm performance". By doing so, we will carry out the tests of the nine hypotheses.

\subsection{Linear Analysis}

On the level of the three models, we raise six variables having a significant influence on the relation "financial 
participation - firm performance" (Table 3):

- The variables "absence of quantitative criteria of the bonus", "multiplicity of the devices", "presence of training programs" and "presence of participative devices" present the same signs which are envisaged by their respective hypotheses. We conclude that the hypotheses H1, H6, H8 and H9 are supported.

- Two variables "value of the bonus" and "presence of communication supports" post contrary signs with those envisaged on the level of their respective hypotheses. We conclude that the assumptions $\mathrm{H} 2$ and $\mathrm{H} 7$ are not supported.

Table 3. Linear meta-regression results

\begin{tabular}{|c|c|c|c|}
\hline & Model (1) & Model (2) & Model (3) \\
\hline \multirow[t]{2}{*}{ Constant } & $0,081 * * *$ & $0,222 * *$ & $0,271 * * *$ \\
\hline & $(4,716)$ & $(2,229)$ & $(4,364)$ \\
\hline \multirow[t]{2}{*}{ Absence of quantitative criteria of the bonus } & $-0,046$ & $-0,193 * * *$ & $-0,230 * * *$ \\
\hline & $(-0,835)$ & $(-3,640)$ & $(-4,921)$ \\
\hline \multirow[t]{2}{*}{ Bonus value } & $-0,009$ & $-0,134 * * *$ & $-0,170 * * *$ \\
\hline & $(-0,218)$ & $(-3,266)$ & $(-5,278)$ \\
\hline \multirow[t]{2}{*}{ Differed payment of bonus } & $-0,111$ & $-0,089$ & \\
\hline & $(-1,522)$ & $(-1,251)$ & \\
\hline \multirow[t]{2}{*}{ Unicity payment of bonus } & $-0,115$ & $-0,110$ & \\
\hline & $(-0,770)$ & $(-0,841)$ & \\
\hline \multirow[t]{2}{*}{ Multiplicity of schemes } & $-0,122 *$ & $-0,310 * * *$ & $-0,325 * * *$ \\
\hline & $(-1,661)$ & $(-4,482)$ & $(-4,999)$ \\
\hline \multirow[t]{2}{*}{ Team size covered by the scheme } & $-0,120$ & 0,045 & \\
\hline & $(-0,760)$ & $(0,306)$ & \\
\hline \multirow[t]{2}{*}{ Presence of supports of communication } & $-0,130 * * *$ & $-0,081 * *$ & $-0,109 * * *$ \\
\hline & $(-2,897)$ & $(-1,991)$ & $(-3,116)$ \\
\hline \multirow[t]{2}{*}{ Presence of training programs } & $0,089 * *$ & 0,050 & $0,076 * *$ \\
\hline & $(2,264)$ & $(1,368)$ & $(2,244)$ \\
\hline \multirow[t]{2}{*}{ Presence of participative devices } & $0,133 * * *$ & 0,004 & \\
\hline & $(4,147)$ & $(0,112)$ & \\
\hline \multirow[t]{2}{*}{ Objective indicator } & & 0,051 & \\
\hline & & $(1,050)$ & \\
\hline \multirow[t]{2}{*}{ Accounting indicator } & & $-0,001$ & \\
\hline & & $(-0,030)$ & \\
\hline \multirow[t]{2}{*}{ Profit-sharing scheme } & & $0,087 * * *$ & $0,106 * * *$ \\
\hline & & $(2,720)$ & $(4,038)$ \\
\hline \multirow[t]{2}{*}{ Regression method } & & $0,247 * * *$ & $0,261 * * *$ \\
\hline & & $(6,462)$ & $(8,108)$ \\
\hline \multirow[t]{2}{*}{ Industrial sector } & & 0,034 & \\
\hline & & $(1,149)$ & \\
\hline \multirow[t]{2}{*}{ United States } & & $-0,016$ & \\
\hline & & $(-0,546)$ & \\
\hline \multirow[t]{2}{*}{ Study publication } & & $-0,050$ & $-0,043$ \\
\hline & & $(-1,654)$ & $(-1,531)$ \\
\hline \multirow[t]{2}{*}{ Sample size } & & $-0,063 * * *$ & $-0,069 * * *$ \\
\hline & & $(-5,144)$ & $(-6,141)$ \\
\hline Number of observations & 226 & 226 & 226 \\
\hline $\mathrm{R}^{2}$ & 0,170 & 0,414 & 0,395 \\
\hline Adjusted $\mathrm{R}^{2}$ & 0,136 & 0,366 & 0,369 \\
\hline $\mathrm{F}$ & $4,920 * * *$ & $8,638 * * *$ & $15,640 * * *$ \\
\hline
\end{tabular}

Note. $* * * * *$ and $*$ denote statistical significance at $1 \%, 5 \%$ and $10 \%$; t-statistics in parentheses; Observations are weighted by standard error of effect sizes. 


\subsection{Logit Meta-Regression}

We raise five variables which have a significant influence on the probability of obtaining a positive impact of financial participation on firm economic performance (Table 4):

- The variable "absence of quantitative criteria of the bonus" presents a negative sign. The firm which does not clearly define the criteria of the bonus that it distributes to its employees sees his probability of improving its economic performance to decrease.

- The variable "value of the bonus" and the variable "presence of supports of communication" present a negative coefficient. These variables decrease the chances to obtain a positive economic impact of the device.

- The variable "presence of training programs" and the variable "presence of participative devices" have a positive coefficient, which means that these two factors positively influence the probability of observing an economic impact of the financial participation scheme.

Table 4. Logit meta-regression results

\begin{tabular}{|c|c|c|c|}
\hline Paramètres & Modèle (1) & Modèle (2) & Modèle (3) \\
\hline \multirow[t]{2}{*}{ Constant } & $-0,190$ & $-4,392 * * *$ & $-3,544 * * *$ \\
\hline & $(1,027)$ & $(12,218)$ & $(23,738)$ \\
\hline \multirow[t]{2}{*}{ Absence of quantitative criteria of the bonus } & $-0,799$ & $-1,529 * *$ & $-1,612 * *$ \\
\hline & $(1,287)$ & $(4,205)$ & $(5,126)$ \\
\hline \multirow[t]{2}{*}{ Bonus value } & $-0,413$ & $-1,243 * *$ & $-1,479 * * *$ \\
\hline & $(0,834)$ & $(6,136)$ & $(11,168)$ \\
\hline \multirow[t]{2}{*}{ Differed payment of bonus } & $-0,264$ & $-0,717$ & \\
\hline & $(0,127)$ & $(0,735)$ & \\
\hline \multirow[t]{2}{*}{ Unicity payment of bonus } & $-41,757$ & $-38,718$ & \\
\hline & $(0,000)$ & $(0,000)$ & \\
\hline \multirow[t]{2}{*}{ Multiplicity of schemes } & $-21,013$ & $-21,802$ & \\
\hline & $(0,000)$ & $(0,000)$ & \\
\hline \multirow[t]{2}{*}{ Team size covered by the scheme } & 20,638 & 19,780 & $-21,630$ \\
\hline & $(0,000)$ & $(0,000)$ & $(0,000)$ \\
\hline \multirow[t]{2}{*}{ Presence of supports of communication } & $-1,086 * *$ & $-1,044 * *$ & $-1,155 * *$ \\
\hline & $(4,581)$ & $(3,860)$ & $(5,582)$ \\
\hline \multirow[t]{2}{*}{ Presence of training programs } & 0,476 & 0,664 & $0,862 *$ \\
\hline & $(1,027)$ & $(1,529)$ & $(3,095)$ \\
\hline \multirow[t]{2}{*}{ Presence of participative devices } & $0,864 * *$ & 0,002 & \\
\hline & $(4,633)$ & $(0,000)$ & \\
\hline \multirow[t]{2}{*}{ Objective indicator } & & 0,207 & \\
\hline & & $(0,144)$ & \\
\hline \multirow[t]{2}{*}{ Accounting indicator } & & 0,317 & \\
\hline & & $(0,341)$ & \\
\hline \multirow[t]{2}{*}{ Profit-sharing scheme } & & $1,530 * * *$ & $1,573 * * *$ \\
\hline & & $(10,040)$ & $(12,704)$ \\
\hline \multirow[t]{2}{*}{ Regression method } & & $2,510 * * *$ & $2,398 * * *$ \\
\hline & & $(12,189)$ & $(13,421)$ \\
\hline \multirow[t]{2}{*}{ Industrial sector } & & 0,492 & 0,507 \\
\hline & & $(1,467)$ & $(1,772)$ \\
\hline \multirow[t]{2}{*}{ United States } & & $0,674 *$ & $0,582 *$ \\
\hline & & $(2,998)$ & $(2,856)$ \\
\hline \multirow[t]{2}{*}{ Study publication } & & 0,403 & \\
\hline & & $(1,171)$ & \\
\hline \multirow[t]{2}{*}{ Sample size } & & 0,005 & \\
\hline & & $(0,002)$ & \\
\hline Number of observations & 226 & 226 & 226 \\
\hline Percent correctly predicted & 62,4 & 73,0 & 70,8 \\
\hline Pseudo $\mathrm{R}^{2}$ & 0,0913 & 0,2217 & 0,2012 \\
\hline Wald Chi Square & $28,417 * * *$ & $69,004 * * *$ & $62,605 * * *$ \\
\hline
\end{tabular}

Note. $* * * * *$ and $*$ denote statistical significance at $1 \%, 5 \%$ and $10 \%$; Wald-statistics in parentheses. 


\subsection{Discussion}

Within the framework of the examination of the conditions which contribute to the improvement of the economic performance, we identified those which relate to the financial participation scheme (structural characteristics of the scheme and specificities of its management) and those which are specific to the firm in which it is adopted (organizational characteristics). Among the hypotheses relating to these conditions, two only were not validated showing significant estimates but of contrary sign to that which is envisaged. We discuss in what follows the results relating to the whole of the hypothesis.

\subsubsection{The Transparency Level of Incentive Remuneration}

The first hypothesis (H1) relating to the variable "absence of quantitative criteria of the premium account" is validated. A conclusion is to be drawn from this result: employees attach importance to the transparency of the financial participation scheme (Van Herpen, 2005). Indeed, to leave to the management the capacity to fix, in a completely random and subjective way, the premium accounts which they will grant to pay reduces the visibility of this type of remuneration.

\subsubsection{The Attractive Dimension of the Bonus}

This aspect is related to the bonus value (H2), the degree of availability of the due sums (H3) and the frequency of their payments (H5). All these factors act favorably on the economic impact of the financial participation. They share the same objective: to maintain the interest which the employee grants to this type of device.

The incitement to the effort which is required through the adoption of a financial participation scheme remains a question of financial remuneration. Indeed, a bonus whose value is significant, which presents a liquid character, i.e. which is available as of its attribution, and which is frequently distributed makes it possible the scheme to keep its inciting character near the employees to provide more efforts (Commeiras, 1998; Saint-Onge, 2000; Coyle-Shapiro et al., 2002; Piekkola, 2005).

\subsubsection{Specificities of the Application of the Financial Participation Scheme}

Within this framework, we treat the question of the multiplicity of the modes of profit-sharing within the firm (H6) and of the size of the profit group (H4).

Multiplicity of the schemes presents unfavourable consequences which are the difficulties of management of more than only one device, in addition to their high costs (Kato \& Morishima, 2003).

Concerning the size of the group, and so that the mode allows mutual control as a solution to the problem of free-riding, the number of the employees which benefit from it must be reduced (Zenger \& Marshall, 2000).

\subsubsection{The Context of the Employees' Financial Participation}

The favorable conditions with the economic impact of the financial participation treated with this level are those relating to the presence of the supports of communication $(\mathrm{H} 7)$, to the presence of the training programs (H8) and to the presence of the participative devices (H9).

The employees' social participation in the firm through the participative devices is seen as essential to the success of a financial participation scheme. The joint presence of these two forms of participation constitutes a "powerful" system helping to improve firm performance (Sesil, 2006).

The firm's communication strategy and targeted training aim to develop the employees competences and to improve of their knowledge of the general environment in which they work. In such a situation, thanks to the comprehension of the effort which is required from them and of the specificities of the total operation of their firm, the employees would contribute more effectively to reach the aimed objectives (Sweins et al., 2009).

\subsubsection{The Methodological Specifities}

We analyze 226 estimates from 70 studies that examine the effect of employees' financial participation on firm performance. Taken together, the studies imply a positive and statistically significant effect. Taken individually, these studies present different estimates. We find that methodological diversities play a role in explaining the differences in studies' results.

The first specificity relates to the nature of the scheme. The variable "profit-sharing" is significant with a positive sign within the framework of the two regressions linear and logistic. This result makes it possible to conclude that studies using profit-sharing as proxy for employees' financial participation tend to report larger positive effects on firm performance.

Our results also suggest that studies which resort to the regression as an econometric method tend to overstate 
the effect of employees' financial participation on firm performance.

\section{Conclusion}

Questions about the relationship between the employees' financial participation and the firm performance are not recent. They were often asked in the academic and professional literature, and the answers brought were compartmental, multiple, different, and even contradictory. The abundance of the literature is the irrefutable proof that this topic is treated under more than one angle so that each time the question of the link between this other form of compensation and the performance of the firms, always remains of topicality.

Aiming to identify the factors which can influence the relationship "financial participation - firm performance", we carried out a qualitative analysis of the literature devoted to this topic. This review enabled us to make an inventory of nine factors that were the subject of the nine hypotheses.

The validation of all these hypotheses was carried out by using the meta-analysis approach. The major advantage of this method is that it combines the findings from independent studies.

Regarding the results obtained, we can affirm that all the hypotheses are checked, except for those relating to the value of the bonus and the presence of supports of communication. All the awaited signs were confirmed except those related to the two latter factors. The introduction of employees' financial participation improves the accounting and stock exchange of firm performance. The factors influencing this impact are related to the three characteristics' categories: The structural characteristics of the scheme: degree of clearness of the bonus criteria, liquidity of the bonus and frequency of the payments (category 1); the multiplicity of schemes and group size (category 2); the presence of training programs and participative devices (category 3 ).

The managerial applications of this research are obvious: the effectiveness of a financial participation scheme can be improved without no pecuniary impact on the firm, only while acting on some factors: transparency of the financial participation scheme, availability and frequency of the bonus, not multiplicity of the schemes within the firm and reduced size group which profits from it, and finally adoption of "high performance human resources practices".

\section{References}

Alchian, A. A., \& Demsetz, H. (1972). Production, information costs and economic organization. American Economic Review, 62(5), 777-795.

Alchian, A. A., \& Demsetz, H. (1973). The Property right paradigm. The Journal of Economic History, 33(1), 16-27. http://dx.doi.org/10.1017/S0022050700076403

Artus, P., Legendre, F., \& Morin, P (1991). Le partage implicite des profits et ses effets sur la productivité du travail. Annales d'Economie et de Statistique, 22, 33-57.

Banker, R. D., Lee, S. Y., Potter, G., \& Srinivasan, D. (2001). An empirical analysis of continuing improvements following the implementation of a performance-based compensation plan. Journal of Accounting and Economics, 30, 315-350. http://dx.doi.org/10.1016/S0165-4101(01)00016-7

Banker, R. D., Lee, S. Y., Potter, G., \& Srinivasan, D. (2004). An empirical examination of the impacts from termination of a performance-based incentive plan. SSRN Working Paper series. Global management accounting research conference, Georgetown University.

Berle, A. A., \& Means, G. C. (1932). The modern corporation and private property. New York, Macmillan.

Bhargava, S. (1994). Profit sharing and the financial performance of companies: Evidence from U.K. panel. The Economic Journal, 104(426), 1044-1056. http://dx.doi.org/10.2307/2235063

Bhattacherjee, D. (2005). The effects of group intensives in an Indian firm: Evidence from pay roll data. Review of Labour Economics and Industrial Relations, 19(1), 143-173.

Blanchflower, D. G., \& Oswald, A. J. (1988). Profit-related pay: Prose discovered? The Economic Journal, 98(392), 720-730. http://dx.doi.org/10.2307/2233910

Borenstein, M., Hedges, L. V., Higgins, J. P. T., \& Rothstein, H. (2009). Introduction to Meta-Analysis. John Wiley and Sons, Ltd., Publication. http://dx.doi.org/10.1002/9780470743386

Bryson, A., \& Freeman, R. (2010). How does shared capitalism affect economic performance in the United Kingdom? In D. L. Kruse, R. B. Freeman, \& J. R. Blasi (Eds.), Shared capitalism at work employee ownership, profit and gainsharing, and broad-based stock options (pp. 201-224). The University of Chicago Press, NBER. http://dx.doi.org/10.7208/chicago/9780226056968.003.0007 
Bryson, A., Freeman, R., Lucifora, C., Pellizzari, M. \& Pérotin, V. (2011). Paying for performance: incentive pay schemes and employees financial participation. In Workshop The economics of share ownership and incentive pay: findings and policy implications. Center for Economic Performance and London School of Economics and Political Sciences (dir.).

Bullock, R. J., \& Lawler, E. E. (1984). Gainsharing: A few questions, and fewer answers. Human Resource Management, 23(1), 23-40. http://dx.doi.org/10.1002/hrm.3930230104

Cable, J. R. (1988). Is profit sharing participating? Evidence on alternative firm types from West Germany. $\begin{array}{lllll}\text { International Journal of Industrial } & \text { Organization, } & 6, & 137 .\end{array}$ http://dx.doi.org/10.1016/0167-7187(88)90010-0

Cable, J. R., \& Fitzroy, F. R. (1980). Productive efficiency, incentive and employee participation: Some $\begin{array}{lllll}\text { preliminary results for } \quad \text { West-Germany. Kyklos, } & \text { 33(1), }\end{array}$ http://dx.doi.org/10.1111/j.1467-6435.1980.tb02623.x

Cable, J. R., \& Wilson, N. (1990). Profit sharing and productivity: Some further evidence. The Economic Journal, 100(401), 550-555. http://dx.doi.org/10.2307/2234140

Cahuc, P., \& Dormont, B. (1997). Profit-sharing: Does it increase productivity and employment? A theorical model and empirical evidence of French micro data. Labour Economics, 4(3), 293-319. http://dx.doi.org/10.1016/S0927-5371(97)00008-0

Coase, A. (1937). The nature of the Firms. Economica, 4(16), 386-405. http://dx.doi.org/10.1111/j.1468-0335.1937.tb00002.x

Conte, M. A., \& Svejnar, J. (1988). Productivity effects of worker participation in U.S. firms. International Journal of Industrial Organization, 6(2), 139-161. http://dx.doi.org/10.1016/0167-7187(88)90011-2

Conyon, M. J., \& Freeman, R. (2001). Shared modes of compensation and firms performance: UK evidence. Working Paper $n^{\circ} 8448$, National Bureau of Economic Research, Cambridge.

Cooke, W. N. (1994). Employee participation programs, group based incentives, and company performance: A union-nonunion comparison. Industrial and Labor Relation Review, 47(4), 594-609. http://dx.doi.org/10.1177/001979399404700405

Coyle-Shapiro, J., Morrow, P. C., Richardson, R., \& Dunn, S. R. (2002). Using profit-sharing to enhance employee attitudes: A longitudinal examination of the effects on trust and commitment. Human Resource Management, 41, 423-439. http://dx.doi.org/10.1002/hrm.10052

D'Art, D., \& Turner, T. (2001). Profit Sharing and performance in Irish companies: A review. Irish Journal of Management, 22(1), 35-54.

D'Art, D., \& Turner, T. (2004). Profit-sharing, firm performance and union influence in selected European countries. Personnel Review, 33(3), 335-350. http://dx.doi.org/10.1108/00483480410528869

Delery, J. E., \& Doty, D. H. (1996). Modes of theorizing in strategic human resource management: Tests of universalistic, contingency and configurational performance predictions. Academy of Management Journal, 39(4), 802-835. http://dx.doi.org/10.2307/256713

Drolet, S., Lanoire, P., \& Shearer, B. (1999). Analyse de l'impact productif des pratiques de rémunération incitative pour une entreprise de service: Application à une coopérative financière québécoise. Working Paper n ${ }^{\circ}$ 995-28, Série Scientifique, CIRANO.

Durant, R. F., Perry, J. L., Mesch, D., \& Paarlberg, L. (2006). Motivating employees in new governance era: The performance paradigm revisited. Public Administration Review, 66, 505-514. http://dx.doi.org/10.1111/j.1540-6210.2006.00611.x

Estrin S., Jones D. C., \& Svejnar, J. (1987). The productivity effects of worker participation: Producer cooperatives in Western Economics. Journal of Comparative Economics, 11, 40-61. http://dx.doi.org/10.1016/0147-5967(87)90040-0

Fakhfakh, F., \& Pérotin, V. (2000). The effects of profit-sharing schemes on enterprise performance in France. Economic Analysis, 3(2), 93-111. http://dx.doi.org/10.1080/713663558

Fitzroy, F., \& Kraft, K. (1985). Participation and division of labour: A West German case study. Industrial Relations Journal, 4, 68-74. http://dx.doi.org/10.1111/j.1468-2338.1985.tb00867.x

Fitzroy, F., \& Kraft, K. (1987). Cooperation, productivity and profit-sharing. Quarterly Journal of Economics, 
102(1), 23-35. http://dx.doi.org/10.2307/1884678

Fitzroy, F., \& Kraft, K. (1992). Forms of profit sharing and firm performance: Theoretical foundations and empirical problems. Kyklos, 45(2), 209-225. http://dx.doi.org/10.1111/j.1467-6435.1992.tb02114.x

Freeman, R. B., Kruse, D. L., \& Blasi, J. R. (2010). Worker responses to shirking under shared capitalism. In D. L. Kruse, R. B. Freeman, \& J. R. Blasi (Eds.), Shared capitalism at work employee ownership, profit and gainsharing, and broad-based stock options (pp. 77-103). The University of Chicago Press, London, National Bureau of Economic Research. http://dx.doi.org/10.7208/chicago/9780226056968.003.0003

Frick, B. J., Goetzen, U., \& Simmons, R. (2013). The hidden costs of high-performance work practices: Evidence from a long German Steel company. Industrial and Labour Relations Review, 66(1), 198-224. http://dx.doi.org/10.1177/001979391306600108

Gielen, A. C., Kerkhofs, M., \& Van Ours, J. C. (2010). How performance related pay affects productivity and employment. Journal of Population Economics, 23, 291-301. http://dx.doi.org/10.1007/s00148-009-0252-9

Glass, G. V. (1976). Primary, secondary, and meta-analysis of research. Educational Researcher, 5(10), 3-8. http://dx.doi.org/10.3102/0013189X005010003

Glass, G. V., \& Smith, M. L. (1979). Meta-analysis of research on class size and achievement. Educational Evaluation and Policy Analysis, 1(1), 2-16. http://dx.doi.org/10.3102/01623737001001002

Guery, L. (2009). Pratiques de mobilisation des salariés et performance financière de l'entreprise: Quels liens? Working Paper $n^{\circ}$ 59, AGRH, Reims.

Helper, S., \& Kleiner, M. M. (2007). International differences in lean production, productivity and employee attitudes. Working Paper n ${ }^{\circ}$ 3015, SSRN, National Bureau of Economic Research.

Holmström, B. (1979). Moral hazard and observability. Bell Journal of Economics, 9, 74-91. http://dx.doi.org/10.2307/3003320

Huang, T. C. (1997). The effects of participative management on organizational performance: The case of Taiwan. The International Journal of Human Resource Management, 8(5), 677-689. http://dx.doi.org/10.1080/095851997341450

Hunter, J. E., \& Schmidt, F. L. (2004). Methods of meta-analysis - Correcting error and bias in research findings. Sage Publications.

Hunter, J. E., Schmidt, F. L., \& Jackson, G. (1982). Meta-analysis: Cumulating research findings across studies. Beverly Hills, Sage Publications.

Jensen, M. C., \& Meckling, W. H. (1976). Theory of the firm, managerial behaviour, agency costs and ownership $\begin{array}{lllll}\text { structure. Journal of } & \text { Financial } & \text { Economics, } & 3(4), & \text { 305-360. }\end{array}$ http://dx.doi.org/10.1016/0304-405X(76)90026-X

Jones, D., \& Kato, T. (1995). The productivity effects of ESOP and bonus: Evidence from Japanese panel data. The American Economic Review, 85(3), 391-414.

Jones, D., \& Svejnar, J. (1985). Participation, profit sharing, worker ownership, and efficiency in Italian producer cooperatives. Economica, 52(208), 449-465. http://dx.doi.org/10.2307/2553878

Jones, D., Kalmi, P., Kato, T., \& Mäkinen, M. (2008). The effects of human resource management practices on firm productivity-Preliminary evidence from Finland. Working Paper $\mathrm{n}^{\circ} 1121$, The Research Institute of the Finnish Economy.

Kalmi, P., \& Sweins, C. (2010). The performance impact of financial participation: subjective and objective measures compared. In T. Eriksson (Ed.), Advances in the economic analysis of participatory and labor-managed firms (Vol. 11, pp. 69-88). Emerald Group Publishing Limited. http://dx.doi.org/10.1108/s0885-3339(2010)0000011007

Kalmi, P., Pendleton, A., \& Poutsma, E. (2005). Financial participation and performance in Europe. Human Resource Management Journal, 15(4), 54-67. http://dx.doi.org/10.1111/j.1748-8583.2005.tb00295.x

Kato, T., \& Morishima, M. (2003). The nature of SCOPE and effects of profit sharing in Japan: Evidence from new survey data. International Journal of Human Resource Management, 14(6), 942-955. http://dx.doi.org/10.1080/0958519032000106155

Kato, T., \& Morishima, M. (2003). The nature of SCOPE and effects of profit sharing in Japan: Evidence from new survey data. International Journal of Human Resource Management, 14(6), 942-955. 
http://dx.doi.org/10.1080/0958519032000106155

Kato, T., \& Morishima, M. (2003). The nature of SCOPE and effects of profit sharing in Japan: Evidence from new survey data. International Journal of Human Resource Management, 14(6), 942-955. http://dx.doi.org/10.1080/0958519032000106155

Kato, T., Lee, J. H., \& Ryu, J. S. (2010). The productivity effects of profit sharing, employee ownership, stock option and team incentive plans: Evidence from Korean panel data. Working Paper $\mathrm{n}^{\circ}$ 5111, IZA. http://dx.doi.org/10.1108/s0885-3339(2010)0000011009

Kelly, P., \& Hounsell, R. W. (2007). Engaging associates and unleashing productivity: The case for simplified gainsharing. Performance Improvement, 46, 30-34. http://dx.doi.org/10.1002/pfi.106

Kim, D. O. (1996). Factors influencing organizational performance in gainsharing programs. Industrial Relations, 35(2), 227-244. http://dx.doi.org/10.1111/j.1468-232x.1996.tb00404.x

Kim, H., \& Gong, Y. (2009). The roles of tacit knowledge and OCB in the relationship between groups based pay and firm performance. Human Relation Management Journal, 19(2), 120-139. http://dx.doi.org/10.1111/j.1748-8583.2009.00093.x

Kim, S. (1998). Does profit sharing increase firm's profits? Journal of Labor Research, 19(2), 351-370. http://dx.doi.org/10.1007/s12122-998-1019-x

Kraft, K. (1991). The incentive effects of dismissals, efficiency wages, piece-rate, and profit sharing. The Review of Economics and Statistics, 73(3), 451-459. http://dx.doi.org/10.2307/2109569

Kraft, K., \& Ugarkovic, M. (2006). Profit sharing and the financial performance of firm: Evidence from Germany. Economics Letters, 92, 333-338. http://dx.doi.org/10.1016/j.econlet.2006.03.008

Kruse, D. (1992). Profit sharing and productivity: Microeconomic evidence from the United States. The Economic Journal, 102(410), 24-36.

Kruse, D. (1993). Does profit sharing affect productivity? Working Paper $n^{\circ} 4542$, National Bureau of Economic Research, SSRN.

Kruse, D., Blasi, J., \& Freeman, R. (2011). Does shared capitalism help the best firms do even better? Center for Economic Performance (dir.). The economics of share ownership and incentive pay: Findings and policy implications. London School of Economics and Political Sciences.

Kumbhakar, S. C., \& Dumbar, A. E. (1993). The elusive ESOP-productivity link: Evidence from US firm-level data. Journal of Public Economics, 52, 273-283. http://dx.doi.org/10.1016/0047-2727(93)90024-N

Lacoursière, R., Fabi, B. \& St-Pierre, J. (2000). Impact de certaines pratiques de GRH sur la performance organisationnelle et financière des PME. Working Paper, $5^{\text {ème }}$ Congrès International Francophone sur la PME, AIREPME, Lille.

Laroche, P., \& Schmidt, G. (2004). La méta-analyse en sciences de gestion: Utilités, utilisations et débats. Working Paper, Academy of Management, Division "Research methods, crossing frontiers in quantitative and qualitative research methods", ISEOR.

Le Roux, A. (1998). Les effets des pratiques d'intéressement sur les performances des entreprises. In J. Allouche, \& B. Sire (Eds.), Ressources Humaines, une gestion éclatée (pp. 315-333). Economica.

Long, R. J. (2000). Employee profit-sharing: Consequences and moderators. Relations Industrielles, 55(3), 477-505. http://dx.doi.org/10.7202/051329ar

Long, R. J. (2005). Group based pay participatory practices, and work place performance. Conference on the Evolving Workplace, Ottawa.

Magnan, M., \& Saint-Onge, S. (2005). The impact of profit-sharing on the performance of financial services firms. Journal of Management Studies, 42(4), 761-791.

Magnan, M., Saint-Onge, S., \& Cormier, D. (2005). The adoption and success of profit-sharing plans in strategic business units: Opportunism or contingency? International Journal of Productivity and Performance, 54(5/6), 355-369. http://dx.doi.org/10.1111/j.1467-6486.2005.00518.x

Matsumura, E. M., \& Shin, J. Y. (2004). An empirical analysis of a relative performance-based incentive plan: Evidence from a postal service. SSRN Working Paper series, Department of Accounting and Information Systems. http://dx.doi.org/10.2139/ssrn.556153 
Miller, C. S., \& Schuster, M. H. (1995). Anatomy of a failure: A non-recommended application of gainsharing and its predictable effects on productivity in a public sector setting. Public Administration Quarterly, 19(2), 217-242.

Mirlees, J. (1976). The optimal structure of incentives and authority within an organization. Bell Journal of Economics, 7, 105-131. http://dx.doi.org/10.2307/3003192

Mitchell, D. J., Lewin, D., \& Lawler III, E. E. (1989). Alternative pay system, firm performance, and productivity. In A. S. Blinder (Ed.), Paying for productivity: A look at the evidence (pp. 15-94). The Booking Institution, Washington.

Ohkusa, Y., \& Ohtake, F. (1997). The productivity effects of information sharing, profit sharing, and ESOPs. Journal of the Japanese and International Economies, 11(3), 385-402. http://dx.doi.org/10.1006/jjie.1997.0372

Patibandla, M., \& Chandra, P. (1998). Organizational practices and employee performance: The case of the Canadian primary textile industry. Journal of Economic Behavior and Organization, 37, 431-442. http://dx.doi.org/10.1016/S0167-2681(98)00116-4

Pendleton, A., \& Robinson, A. (2011). The economic effects of multiple incentives. Working Paper. In Center for Economic Performance and London School of Economics and Political Sciences (dir.), The economics of share ownership and incentive pay: Findings and policy implications.

Pendleton, A., Poutsma, E., Van Ommeren, J., \& Brewster, B. (2003). The incidence and determinants of employee share ownership and profit sharing in Europe. In Advances in the economic analysis of participatory and labor-managed firms (Vol. 7, pp. 141-172). Emerald Group Publishing Limited. http://dx.doi.org/10.1016/S0885-3339(03)07008-X

Piekkola, H. (2005). Performance related pay and firm performance in Finland. International of Manpower, 26 , 619-635. http://dx.doi.org/10.1108/01437720510628103

Pouliakas, K., \& Theodoropoulos, N. (2009). Variety of performance pay and firm performance: Effect of financial incentives on worker absence and productivity. Working Paper $\mathrm{n}^{\circ} 18820$, Munich Personal RePEc Archive (MPRA).

Poutsma, E. (2001). Les tendances récentes de la participation financière des travailleurs dans l'Union Européenne. Working Paper, Fondation Européenne pour l'amélioration des conditions de vie et de travail.

Poutsma, E., \& Braam, G. (2012). Financial participation plans and firm financial performance: Evidence from a Dutch longitudinal panel. In Bryson, A. (Ed.), Advances in the economic analysis of participatory and labor-managed firms (Vol. 13, pp. 141-185). http://dx.doi.org/10.1108/s0885-3339(2012)0000013010

Ramos, L. M. (2002). Profit sharing in Portugal: why higher productivity? Review of Labour Economics and Industrial Relations, 16(1), 157-175.

Robinson, M., \& Wilson, N. (2006). Employee financial participation and productivity: An empirical reappraisal. British Journal of Industrial Relation, 44(1), 31-50. http://dx.doi.org/10.1111/j.1467-8543.2006.00486.x

Roman, F. J. (2009). An analysis of changes to a team-based incentive plan and its effects on productivity, product quality, and absenteeism. Accounting, Organization and Society, 34, 589-618. http://dx.doi.org/10.1016/j.aos.2008.08.004

Rosenthal, R. (1987). Judgment studies: Design, analysis, and meta-analysis. Cambridge: Cambridge University Press. http://dx.doi.org/10.1017/CBO9780511527807

Rosenthal, R., \& DiMatteo, M. R. (2001). Meta-analysis: Recent developments in quantitative methods for $\begin{array}{lllll}\text { literature } & \text { reviews. Annual Review of Psychology, } & 52, & 59-82 .\end{array}$ http://dx.doi.org/10.1146/annurev.psych.52.1.59

Saint-Onge, S. (1994). Reconnaître les performances. Gestion, 19(3), 88-98.

Saint-Onge, S. (2000). Variables influencing the perceived relationship between performance and pay in a merit pay environment. Journal of Business and Psychology, 14, 459-479. http://dx.doi.org/10.1023/A:1022932317340

Sesil, J. C. (2006). Sharing decision-making and group incentives: The impact on performance. Economic and Industrial Democracy, 27(4), 587-607. http://dx.doi.org/10.1177/0143831X06068998

Shepard, E. M. (1994). Profit sharing and productivity: Further evidence from the chemicals industry. Industrial 
Relations, 33(4), 452-466. http://dx.doi.org/10.1111/j.1468-232x.1994.tb00351.x

Stanley, T. D., \& Jarrell, S. (1989). Meta-regression analysis: A quantitative method of literature surveys. Journal of Economic Surveys, 3(2), 161-170. http://dx.doi.org/10.1111/j.1467-6419.1989.tb00064.x

Sweins, C., Kalmi, P., \& Hulkko-Nyman, K. (2009). Personnel knowledge of the pay system, pay satisfaction and pay effectiveness: Evidence from Finnish personnel funds. The International Journal of Human Resource Management, 20(2), 457-477. http://dx.doi.org/10.1080/09585190802673528

Teixeira, E. G., Basso, L. F., \& Martin, D. M. (2003). Factors that influence operating performance through the use of earnings or gainsharing plans: Evidence in Brazil's chemical industry. SSRN Working Paper series.

Van Herpen, M., Van Praag, M., \& Cools, K. (2005). The effects of performance measurement and compensation on motivation: An empirical study. De Economist, 153(3), 303-329. http://dx.doi.org/10.1007/s10645-005-1990-z

Vaughan-Whitehead, D. (1992). Intéressement, participation, actionnariat: Impacts économiques dans l'entreprise. Economica.

Voos, P. B. (1987). Managerial perceptions of the economic impact of labor relations programs. Industrial and Labor Relation Review, 40(2), 195-208. http://dx.doi.org/10.1177/001979398704000203

Wadwani, S., \& Wall, M. (1990). The effect of profit sharing on employment, wages, stock returns and productivity: Evidence from UK micro-data. The Economic Journal, 100, 1-17. http://dx.doi.org/10.2307/2233593

Wagner, J. A., Rubin, P. A., \& Callahan, T. (1988). Incentive payment and nonmanagerial productivity: An interrupted times series analysis of magnitude and trend. Organizational Behavior and Human Decision Process, 42, 47-74. http://dx.doi.org/10.1016/0749-5978(88)90019-2

Williamson, O. E. (1980). The organization of work: A comparative institutional assessment. Journal of Economic Behavior and Organization, 1, 5-38. http://dx.doi.org/10.1016/0167-2681(80)90050-5

Williamson, O. E. (1981). The modern corporation, origins, evolution, attributes. Journal of Economic Literature, $19,1537-1568$.

Wilson, D. B. (2009). Systematic coding. In H. Cooper, L. V. Hedges, \& J. C. Valentine (Eds.), The handbook of research synthesis and meta-analysis (pp. 159-176). Russell Sage Foundation.

Wolf, F. M. (1986). Meta-analysis: Quantitative methods for research synthesis. Working Paper $n^{\circ} 59$, Sage University.

Yao, S. (1997). Profit sharing, bonus payment, and productivity: A case study of Chinese state owned enterprises. Journal of Comparative Economics, 24(3), 281-296. http://dx.doi.org/10.1006/jcec.1997.1435

Zenger, T. R., \& Marshall, C. R. (2000). The determinants of incentive intensity in group-based rewards. Academy of Management Journal, 43(2), 149-163. http://dx.doi.org/10.2307/1556373

\section{Copyrights}

Copyright for this article is retained by the author(s), with first publication rights granted to the journal.

This is an open-access article distributed under the terms and conditions of the Creative Commons Attribution license (http://creativecommons.org/licenses/by/3.0/). 